\title{
Dependency of domestic food sectors on imported inputs with Finland as a case study
}

\author{
Ellen Huan-Niemi ${ }^{1}$, Marja Knuuttila ${ }^{2}$, Eero Vatanen ${ }^{3}$ and Jyrki Niemi ${ }^{1}$ \\ ${ }^{1}$ Natural Resources Institute Finland (Luke), Latokartanonkaari 9, 00790 Helsinki, Finland \\ ${ }^{2}$ Natural Resources Institute Finland (Luke), Lönnrotinkatu 7, 50100 Mikkeli, Finland \\ ${ }^{3}$ University of Eastern Finland, KTL, Yliopistokatu 2, 80100 Joensuu, Finland \\ e-mail: ellen.huan-niemi@luke.fi
}

\begin{abstract}
The objective of this study is to examine the import dependency of domestic food and service sectors in Finland and produce indicators for measuring the import content of these sectors together with the import dependency of the inputs supplied into these sectors. Input-output analysis is utilised to provide the necessary information on the interdependencies and linkages between different industries for both goods and services in the Finnish economy. Primary agriculture, food processing, distribution and food service providers in Finland are heavily dependent on imported fossil fuels concerning energy and chemical inputs, including high reliance on imported supplementary protein feed for livestock production. However, most of the inputs supplied to the Finnish food and service sectors are domestic because only $20 \%$ of the total output is dependent on imported goods, services, and capital goods. The rate of self-sufficiency in food supply is high in Finland, but international trade is essential to provide the necessary energy and chemical inputs needed for food production along with livestock's supplementary protein feed. Replacing fossil energy with sustainable renewable energy will reduce the dependence on Russia for energy supply and promoting human consumption of plant-based foods will reduce the demand for livestock feed.
\end{abstract}

Key words: self-sufficiency, food sectors, international trade, fossil energy, supplementary protein feed, input-output analysis

\section{Introduction}

Food is produced predominantly to secure domestic food supply and only secondarily for export. Countries strive to develop national policies and pathways toward self-reliance in food production for food security reasons (BaerNawrocka and Sadowski 2019). Food security is a measure of food supply (the availability of food), individuals' ability to access it, and other dimensions as well (FAO 2006). Porkka et al. (2013) highlighted the importance of food trade for food supply: in the beginning of the study period (1965-2005), insufficient domestic production meant insufficient food supply, but at the end of the study period the food deficit has been increasingly compensated by rising food imports. Therefore, moving from food insufficiency towards a rising dependency on food trade is a concern because the links between food security and agricultural trade are inherently complex (D'Odorico et al. 2014).

Most countries consider the ability to ensure food supplies in times of crisis to be a national security issue and invest in their domestic agricultural production because of the risk that imports will be cut off due to conflicts, political tensions, and natural disasters (Clapp 2017). Security of food supply requires resilient food production and supply chains, effective international trade relations, functioning logistics and infrastructure as well as the availability of agricultural inputs are secured. However, the world is becoming increasingly unstable and uncertain due to climate change, global pandemics, destruction of ecosystems, geopolitical tensions and commodity price fluctuations (Tilman et al. 2001, Foley et al. 2005, Godfray et al. 2010). Large scale shocks, such as the COVID-19 pandemic outbreak, are causing exceptional global economic impact (Addison et al. 2020) and national challenges to the health and functioning of human society (Sen 2020). Continuing the flow of agricultural inputs between countries, even in quarantine restrictions or closing borders, is vital for the proper functioning of food production. Therefore, measures to facilitate the trade of farming inputs such as machinery, fertilizers, pesticides, and animal feed should be taken seriously because these requirements are crucial for food production activities to continue smoothly (FAO 2020).

There are numerous studies on self-sufficiency in food production the country level (e.g. Ghose 2014, Wegren and Elvestad 2018, Hamilton-Hart 2019), but studies concerning the dependencies of food sectors on imported and domestic inputs in detail at the country level are scarce. With Finland as a case study, the objective of this study is to assess the dependency of domestic food sectors on imported agricultural inputs, intermediate inputs, and raw materials as well as services. How dependent is agricultural production and the Finnish food sectors on imported goods and services? This involves tracing the inputs imported and utilised in the agricultural and food 
sectors in Finland. More specifically, this study produces indicators for measuring the import content of the domestic food and service sectors plus the import dependency of the inputs supplied into these sectors. There is national interest in Finland to discover and study country-specific complexities within the food sectors due to the outbreak of COVID-19 pandemic and its effects on domestic food production.

The calculation of import dependency in food production requires that both direct and indirect raw materials along with intermediate inputs are considered. Direct imports refer to goods and services that are imported to the sectors where the inputs are directly used. By tracing the indirect imports of inputs engaged in the process of production and service provision, the sum of all imports that indirectly end up in a sector's production process from other sectors are therefore included in the supply chain. This provides a deeper picture of a sector's total dependency on imports. An output-driven input-output analysis is used to calculate the direct imported inputs together with the indirect imported inputs. Although input-output analysis is widely used to study import dependency of foreign trade and the economy as a whole (Cuihong and Jiansuo 2007, Loschky and Ritter 2007, Marshall 2011, Bravo and Álvarez 2012, Ayas 2017), there are very few studies analysing import dependency of food sector using input-output modelling.

\section{Material and methods}

Input-output (IO) analysis is a modelling technique (Leontief 1936) that provides necessary information on the interdependencies and linkages between different industries for both goods and services in the economy. Therefore, domestic and imported inputs in different industries of an economy can be examined. The combination of both goods and services can only be calculated in monetary values and not possible in physical quantities. In addition, both the required direct inputs and indirect inputs of an industry can also be calculated.

\section{The input-output model}

The imported inputs supplied into the food industries are calculated by using the input-output model (see Knuuttila et al. 2007, Ahtikoski et al. 2011), which is the application of the Leontief's basic model (Equation 1).

$\mathrm{X}=(I-A)^{-1} \mathrm{~F}$,

where $\mathbf{X}$ is the vector of outputs, $\mathbf{F}$ is the vector of final demands, $\mathbf{A}$ is the matrix of fixed input coefficients ( $\mathbf{A}=\mathbf{Z} \widehat{\mathbf{X}}^{-\mathbf{1}}$, and $\mathbf{Z}$ is the matrix of intermediate uses) and $\mathbf{I}$ is the identity matrix. The so-called Leontief's inverse matrix (I-A) $)^{-1}$ represents a multiplier used to calculate the overall relationships in industrial outputs caused by final demands. For a more complete account of the input-output analysis, see Miller and Blair (2009).

This study utilises the output-driven, instead of the traditional demand-driven, input-output model.

In the output-driven input-output model, the outputs of industries are dependent on the outputs of other industries. Szyrmer (1992) generated the multiplier matrix of the output-driven model (Equation 2) from the inverse of the Leontief matrix in the following way:

$T F=(I-A)^{-1} \widehat{D}^{-1}$,

where $\widehat{D}$ refers to a diagonal matrix based on the Leontief inverse matrix. Thus, the TF matrix captures the multiplier effects of a unit of the output (Szyrmer 1992, Knuuttila et al. 2007).

The output-driven model is best suited to explain the existing structures and interactions between different industries (Szyrmer 1992). It describes the effects related to the output of the industry in question at a given point in time. The overall effects of a change in the output of a particular industry on the other industries is obtained in the model by multiplying the diagonal matrix composed of the outputs of all industries ( $\widehat{X}$ ) by the TF matrix (Vatanen 2001).

$R=(T F) \hat{X}$ 
The diagonal cells of the matrix $\mathbf{R}$ in Equation 3 indicate the outputs of different industries, and the off-diagonal column cells indicate the direct and indirect output requirements of the industry represented by the row (i) with the output of the industry denoted by the column (j). The sum of the column is the total impact of the industry (j) on the economy.

\section{The import effects of the output}

The value of imported goods and services in the production of an industry in respect to the output value of the industry is the direct rate of import in the industry. The direct rate of import is defined in Equation 4 for one industry and the direct rates of import for all industries in Equation 5.

$$
\begin{aligned}
& m_{j}=\frac{M_{j}}{X_{j}}, \\
& m^{\prime}=M^{\prime} \hat{X}^{-1},
\end{aligned}
$$

where $\widehat{\mathrm{X}}^{-1}$ is the inverse of diagonal matrix of all industries' outputs and $\mathbf{M}^{\prime}$ is a row vector of all industries' direct imports $j$.

The industry's output contains also indirect imports, which are included in the domestic intermediates bought by the industry from other industries to be utilised as inputs in its own production. Thus, the total rate of imported inputs $\left(\mathbf{m t}_{\mathbf{j}}\right.$ ) in industry $j$ is the direct import plus the indirect import divided by the output of industry $j$. Thus, $\mathbf{m t}^{\prime}$ is a row vector which includes the rates of the total imported inputs in all industries. The methods for the calculations are presented in Equation 6 and 7.

$$
m t_{j}=\frac{M_{j}+I M_{j}}{X_{j}},
$$

where $\mathbf{X}_{\mathbf{j}}, \mathbf{M}_{\mathbf{j}}$ and $\mathbf{I} \mathbf{M}_{\mathbf{j}}$ are the output, the direct and indirect import of the industry $j$,

$$
m t^{\prime}=m^{\prime} R \hat{X}^{-1}
$$

\section{The imported products of the output}

The total imported amounts (in euros) of different goods and services required for the output of industries can be calculated by the imports of different industries. For this purpose, the rate of direct imports by product or service in each industry is determined in Equation 8.

$$
m c=M C \hat{X}^{-1},
$$

where the matrix $\mathbf{M C}$ includes the direct imports of different products by industries.

The total amount of different imports required by each industry $j$ can be calculated using the matrix $\mathbf{R M C}^{j}$, which is obtained by multiplying the mc matrix by the diagonal matrix formed from column $j$ of the output matrix $\widehat{\boldsymbol{R}}_{j}$ (Equation 9). The column of matrix indicates how much of the output from industry $j$ would demand outputs from different industries and how much of these outputs would require the imports of different products or services $=$ the cells of the columns in matrix $\mathbf{R M C}^{j}$. The sums of rows in this matrix reveal how much of each input must be imported for the output of industry $j$ (Equation 10). The total imports of different inputs required by the output of industry $j$ is the sum of all cells in the matrix $\mathbf{M C}^{j}$ (Equation 11).

$$
\begin{aligned}
& R M C^{j}=m c \hat{R}_{j} \\
& M C_{i}^{j}=R M C^{j} i \quad \boldsymbol{i}=\text { unit vector (column) } \\
& M C^{j}=i^{\prime} M C_{i}^{j} \quad ;=\text { unit vector (row) }
\end{aligned}
$$

where $\mathbf{M C}_{\mathbf{j}}=\mathbf{M}_{\mathrm{j}}+\mathbf{I} \mathbf{M}_{\mathbf{j}}$ 


\section{The rate of imported inputs in all food industries (import dependency)}

The rate of imported inputs in all food industries is calculated by removing the duplicative parts of the import effects on the food industries. Part of the indirect import of each food industry, which is the direct import of some other food industry, is duplicative. Vatanen $(2001,2011)$ presents how the duplicative parts of the direct and indirect import effects can be eliminated from the total effects of the industry output.

$$
M R=\widehat{m} R
$$

MR is the analytical matrix of industries' total imports (Equation 12). Its diagonal cells indicate the direct imports of industry in columns and the off-diagonal cells indicate the indirect imports of industry in rows, which are required for producing the output of the particular industry. The sum of columns indicates the total imports.

The net imports of industries (NM) in Equation 13 is obtained by adding the direct imports of a particular industry (M) with its effects on the total imports of other industries (the sum of MR in columns) and reducing the import of other industries from that particular industry (the sum of MR in rows).

$$
N M=M+i^{\prime} M R-M R i
$$

In the case of industry $\boldsymbol{j}$, the net imports of $\boldsymbol{j}$ are presented in Equation 14

$$
N M_{j}=M_{j}+\sum_{i}^{n} M R_{i j}-\sum_{j}^{n} M R_{i j}
$$

By using the net imports effect calculation method presented above, the total imported inputs required by the food and service industries can be derived. Hence, the total imported inputs required by the food and service industries $C E M_{\mathrm{e}}$ is presented in Equation 15

$$
\begin{aligned}
& i, j=1, \ldots, n \\
& e *, e \in i, j=a-d, h-m, p, q, s: \text { food industries } \\
& \text { IF } \mathrm{e}^{*}=\mathrm{e}, \text { so } M R_{e e *}=0 .
\end{aligned}
$$

The import dependency $\left(\mathrm{m}_{\mathrm{ea}}\right)$ is calculated by dividing the required total imported inputs of the food and service industries with the total outputs of these industries (Equation 16)

$$
m_{e a}=\frac{C E M_{e}}{F X}=\text { the rate of imported inputs in all food industries }
$$

where $F X=\sum_{e} X_{e}=$ the total outputs of all food industries.

\section{The limitations of input-output analysis}

The simulations made by the input-output model are performed with the current fixed coefficients for inputs needed in production. Hence, the results of the input-output analysis illustrate a situation where all production in the economy is created by the production technology at the year 2016 without any changes in the use of labour, capital or intermediate products utilised in the different industries. In other words, it tells us about the industrial inter-relationships and inter-dependencies of the economy at a point of time, but nothing as to how technical coefficients would change with changed conditions. The assumption of fixed coefficients of production ignores the possibility of factor substitution, although there is always possibility of some substitutions even in the short term, and the substitution possibilities are likely to be more in the long term. Therefore, the results may overestimate the import dependency of domestic output.

The results for the import dependency rates can be affected by the monetary values of the inputs and final products. The value of the final products consists of raw materials and other intermediate inputs, processing costs and services as well as other value-added features in the food chain. This means that the estimated import dependency rates may differ from calculations based on physical quantities. Therefore, the results may underestimate the import dependency of domestic output. 


\section{Data}

The input-output tables (IOTs) for the analysis of year 2016 are provided by Statistic Finland (2020a). The IOTs are based on the supply and use tables (SUTs) of national accounting (Statistic Finland 2020b). The SUTs provide the details of product flows in the national economy. The IOTs are suited for analysing production activity structures and interdependencies between industries, including the imported inputs. The total inputs of the industries provided by Statistics Finland (2020c) are divided into 75 product groups according to the Standard Industrial Classification TOL 2008, which is based on the EU's classification of economic activities (NACE).

In this study, the Finnish food and service sectors are divided into 15 sub sectors: primary agriculture sector, fishing \& aquaculture sector, 10 processing sectors, wholesale sector, retail sector, and the restaurants \& food services sector. The total inputs of the industries are aggregated into 20 product groups according to the statistical classification provided by Statistics Finland (2020c).

In addition to the input-output tables provided by Statistic Finland, foreign trade statistics provided by the Uljas statistical database (Finnish Customs 2020) is utilised to interpret the import dependency results from the inputoutput model. The foreign trade statistics also provide information on the quantities as well as the values of the imported goods and services.

\section{Results}

The total value of Finnish food markets (reflecting total consumption) is $€ 33$ billion in 2016 (Fig. 1). In addition to the production output from the domestic food sectors, the total value of Finnish food markets includes ready-toeat foods that have been imported for domestic consumption but excludes the value of exported food products. The total value of imported goods and services is $€ 8.5$ billion, whereby $€ 5.6$ billion is the value of imported inputs for domestic production, and $€ 2.9$ billion is the imports of prepared food products (ready-to-eat foods). The value of imported inputs is nearly twice the value of prepared food products. The import dependency of the Finnish food markets is $25 \%$ by considering both the inputs (including imports of capital goods) utilised in the domestic food chain and the imported ready-to-eat foods for domestic consumption.

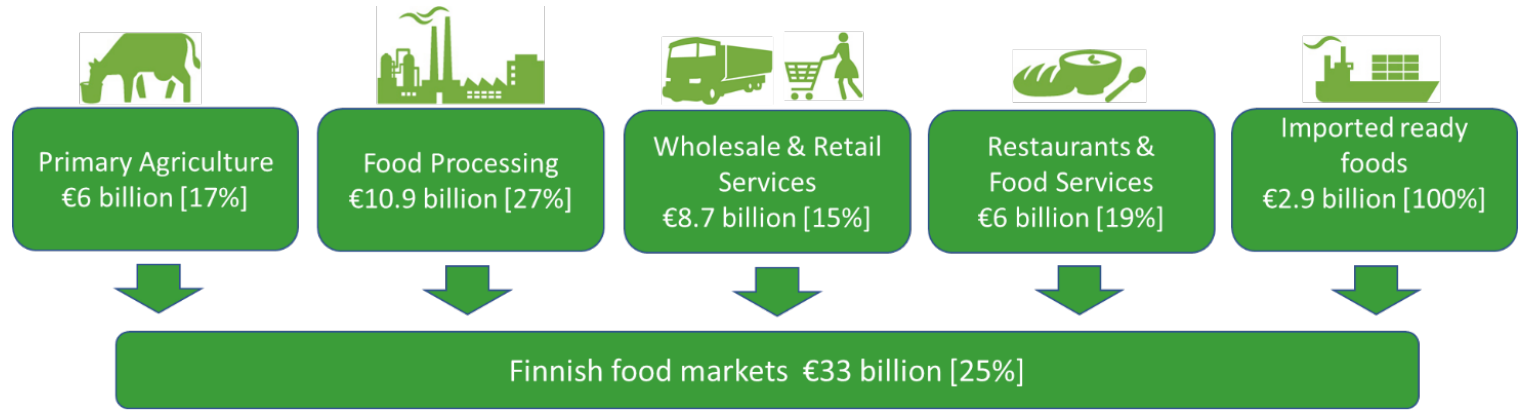

Fig. 1. The total value of Finnish food markets and dependency on imports (in percentage) in 2016 (Knuuttila and Vatanen 2021)

The total output of Finnish food and service sectors (reflecting total production) is $€ 31.9$ billion in 2016, including the exported food products. The rate for import dependency of domestic food production has been examined in Finland since 2008 because detailed input-output data for the period 2008-2016 (Statistics Finland 2020a) is available for analysis. However, this study is focusing on the results for 2016 with the most recent available data. The rate for import dependency of domestic food production in 2016 is approximately $18 \%$, which is the same rate at the beginning of the examination period in 2008 . The import dependency rate has varied between $16 \%$ to $18 \%$ during the years 2008-2016 (see Fig. 2), but the rate has remained close to $18 \%$ for most of the time. Therefore, 2016 is a representative year and it includes new developments in the domestic food sectors. 


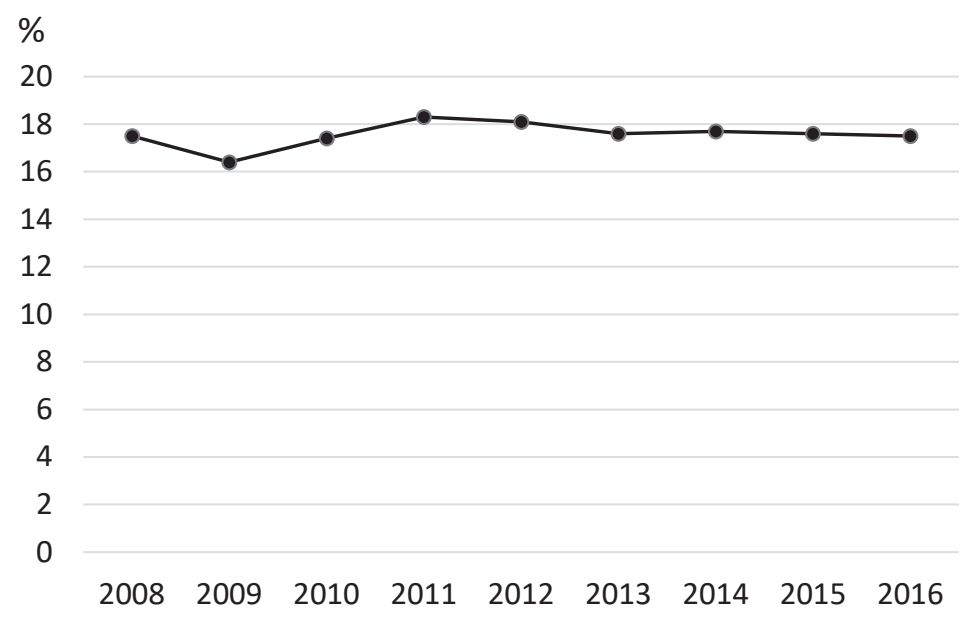

Fig. 2. The rates (\%) for import dependency of domestic food production from 2008-2016, excluding imports of capital goods and imported ready-to-eat foods (Knuuttila and Vatanen 2021)

In this study, the Finnish food and service sectors are divided into 15 sub sectors (Fig. 3). In 2016, the $18 \%$ rate for import dependency of domestic food production is without capital goods. The import dependency of domestic food production is $\mathbf{2 0} \%$, if the imports of capital goods is taken into account. Therefore, the Finnish food and service sectors are mainly reliant on domestic supply of inputs, whereby only $20 \%$ of the total output is dependent on imported goods and services as well as capital goods.

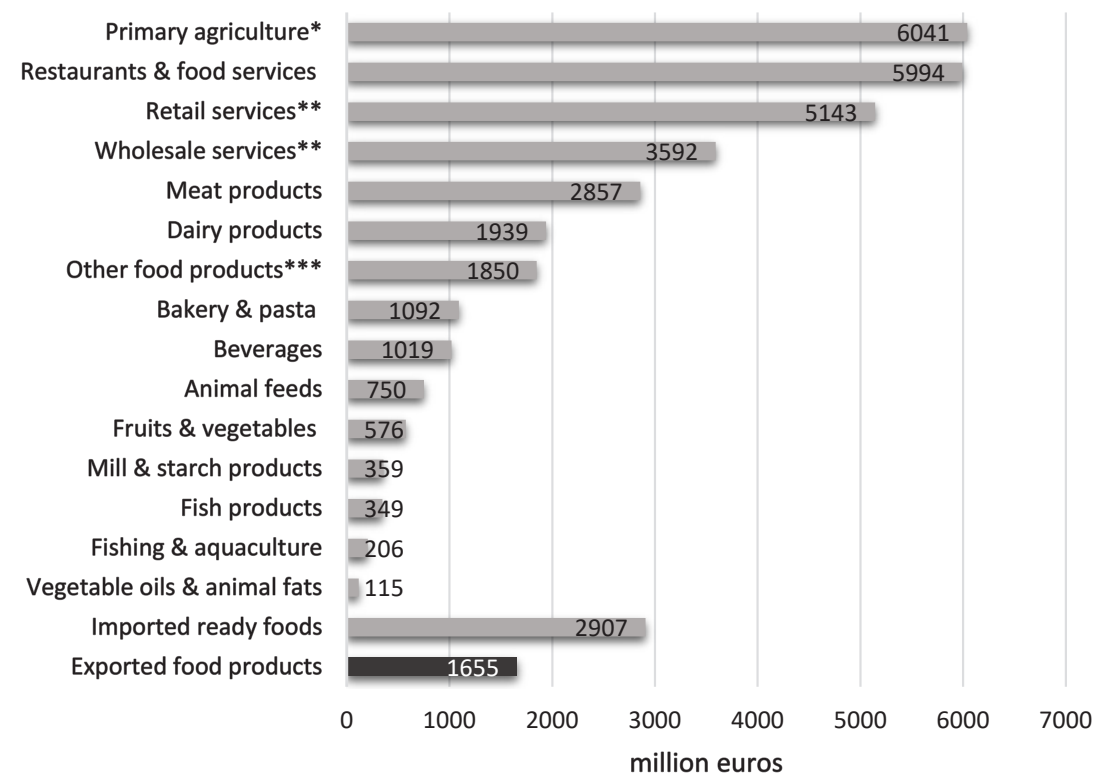

Fig. 3. Total output from the Finnish food and service sectors ( $€ 31.9$ billion, including exported food products) with the total value of exported food products ( $€ 1.7$ billion) and imported readyto-eat foods ( $€ 2.9$ billion) in 2016

*Primary agriculture includes traditional crop and livestock production, horticulture and other livestock production (reindeer, bees, fur animals). The output includes about $€ 1.547$ billion of agricultural subsidies. **The output of retail and wholesale does not include the value of the goods sold, but only the valueadded function.

***Other food products include sugar, confectionery, coffee, tea, spices, condiments, specialty foods and the preparation of prepared meals, i.e. sectors which are not presented as their own food sectors. 


\section{Primary agriculture}

Primary agriculture in Finland is mainly dependent on domestic supplies, whereby only 17\% (Fig. 1) of the total output is dependent on imported goods and services. Regarding the total imports of farming inputs (Fig. 4), "chemicals \& chemical products" represent the largest share with $28 \%$ of primary agriculture's total imports of inputs needed for production. However, this percentage does not show how dependent is primary agriculture on imported "chemicals \& chemical products". When the total supply of "chemicals \& chemical products" to primary agriculture is examined, $68 \%$ of the supplied products are imported. This indicate that only $32 \%$ of the total supply of "chemicals \& chemical products" to primary agriculture is domestic and the majority is imported inputs. Similarly, $78 \%$ of the total supply of "mining \& quarrying products" to primary agriculture is imported, thus indicating that the bulk of total supply is not domestic. "Oilseeds" represent the second largest share with $12 \%$ of primary agriculture's total imports of inputs needed for production. In the same way, $86 \%$ of the total supply of "oilseeds" to primary agriculture is imported, hence showing that supplementary protein feed for livestock production is mostly imported to Finland. The results demonstrate that primary agriculture in Finland is heavily dependent on imported fossil fuels concerning chemical and energy inputs required for primary agricultural production as well as high dependence on the imports of supplementary protein feed for livestock production. The high import dependency of "oilseeds" is also validated by the protein balance sheet calculated by Niemi and Niskanen (2019) to examine the self-sufficiency of protein availability in Finland.

Categories such as "motor vehicles and trailers", "computers, electronic \& optical products", "other food products" have very high import dependency; however, these are representing only small shares in the total imports of inputs needed for production. The category "motor vehicles and trailers" includes motor vehicles for transporting goods or passengers along with various spare parts, accessories, the maintenance and repair of trailers and semitrailers. Agricultural machinery such as agricultural tractors are excluded and considered as capital goods. The category "computers, electronic \& optical products" includes computers, computer peripherals, communications equipment, and similar electronic products, as well as components for such products. The category "other food products" includes soups, broths, yeast, artificial honey and caramel, food supplements and other food products.

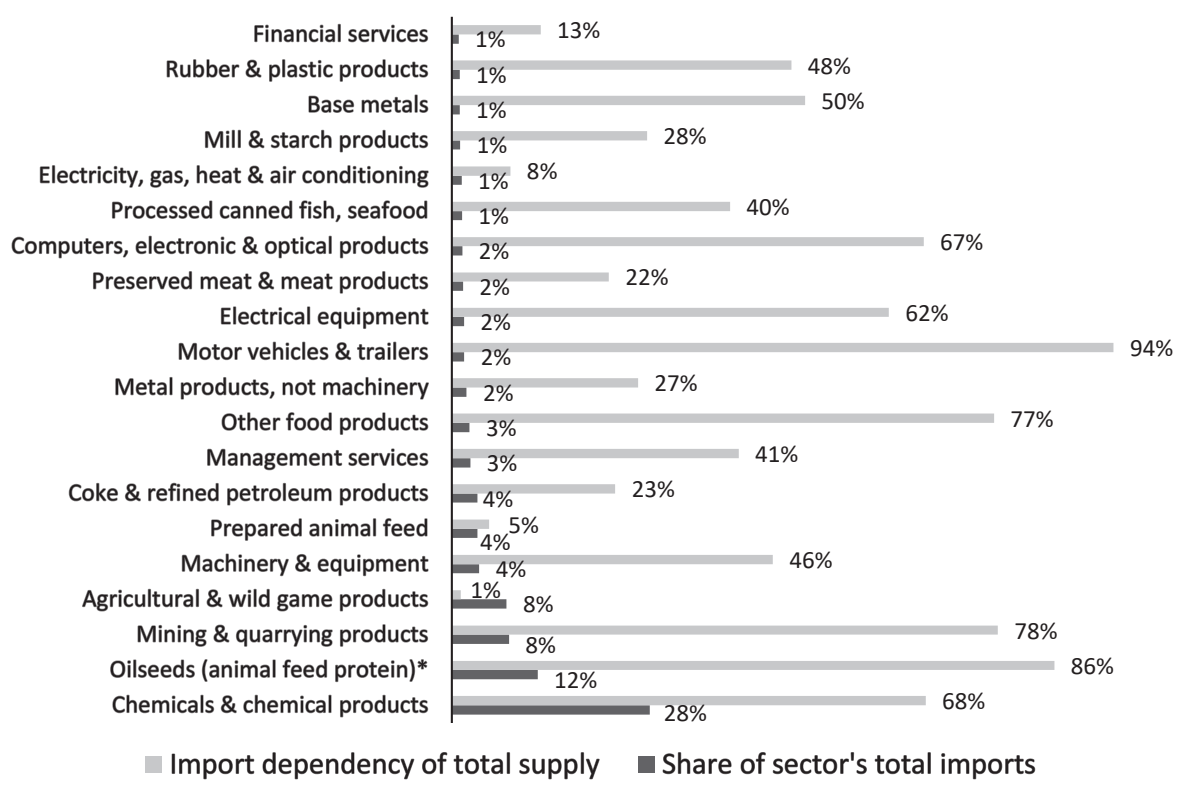

Fig. 4. Primary agriculture dependency on imports for the total supply of direct and indirect inputs into the sector

*In the category of "Vegetable oils \& animal fats"

\section{Food processing}

Food processing in Finland is mainly dependent on domestic supplies, whereby only $27 \%$ (Fig. 1) of the total output is dependent on imported goods and services. The dairy products sector (Fig. 5) is chosen as an example to demonstrate how dependent is food processing on imported inputs because milk production is the largest agricultural 
sector in Finland. "Chemicals \& chemical products" signify the largest share with $18 \%$ of dairy products sector's total imports of inputs needed for dairy production. When the total supply of "chemicals \& chemical products" to the dairy products sector is examined, $73 \%$ of the supplied chemical products are imported. This is an indication that the dairy products sector is highly dependent on imported "chemicals \& chemical products". However, the highest import dependency of total supply is from "oilseeds" with $82 \%$, but "oilseeds" represent only $5 \%$ of dairy products sector's total imports of inputs needed for production. Similarly, $77 \%$ of the total supply of "mining \& quarrying products" to the dairy products sector is imported, but "mining \& quarrying products" represent only $5 \%$ of dairy product sector's total imports of inputs needed for production. The results demonstrate that the dairy products sector, comparable to primary agriculture, is heavily dependent on imported fossil fuels concerning chemical and energy inputs required for dairy production as well as high dependence on the imports of supplementary protein for livestock feed in milk production.

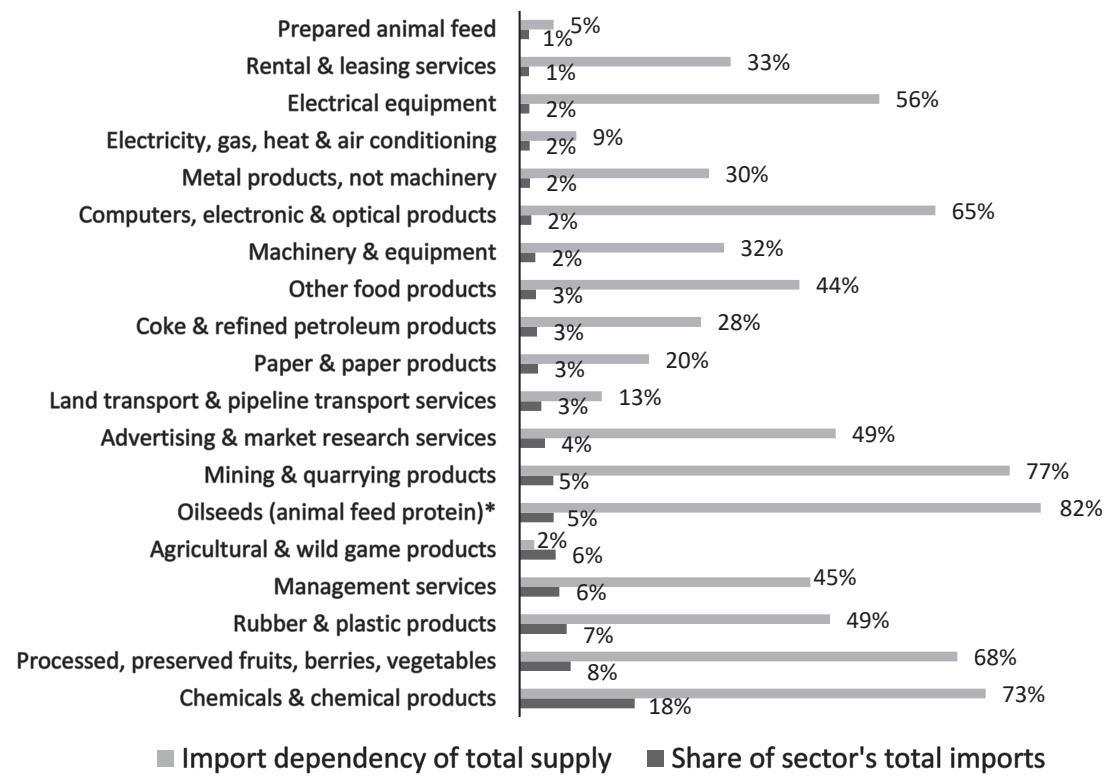

Fig. 5. Dairy products dependency on imports for the total supply of direct and indirect inputs into the sector

*In the category of "Vegetable oils \& animal fats"

\section{Wholesale and retail services}

Wholesale and retail services in Finland are mainly dependent on domestic supplies, whereby only 15\% (Fig. 1) of the total output is dependent on imported goods and services. The retail sector (Fig. 6) is chosen as an example to demonstrate how dependent is the food distribution sector on imported inputs. "Management services" represent the largest share with $25 \%$ of the retail sector's total imports of inputs needed for providing the retail services, whereby $59 \%$ of the utilised "management services" are imported. Management services include legal and accounting activities as well as business management consulting services related to the operation of head offices. "Rental \& leasing services" signify the second largest share with $12 \%$ of the retail sector's total imports of inputs needed for providing the retail services, whereby $69 \%$ of the utilised "rental \& leasing services" are imported. "Rental and leasing services" include activities that provide a wide array of tangible goods, such as automobiles, computers, consumer goods, and industrial machinery and equipment for a periodic rental or lease payment. In comparison to "management services", "chemicals \& chemical products" stand for only $3 \%$ of the retail sector's total imports of inputs needed for providing the retail services, but the import dependency of total supply is equally as high with 59\%. Likewise, "mining \& quarrying products" represent only $4 \%$ of the retail sector's total imports of inputs needed for providing the retail services, however the import dependency of total supply is among the highest with 69\%. The results reveal that the retail services in Finland are not only dependent on the imports of "management services" and "rental \& leasing services", but also very dependent on imported fossil fuels concerning energy and chemical inputs required for distribution services. 


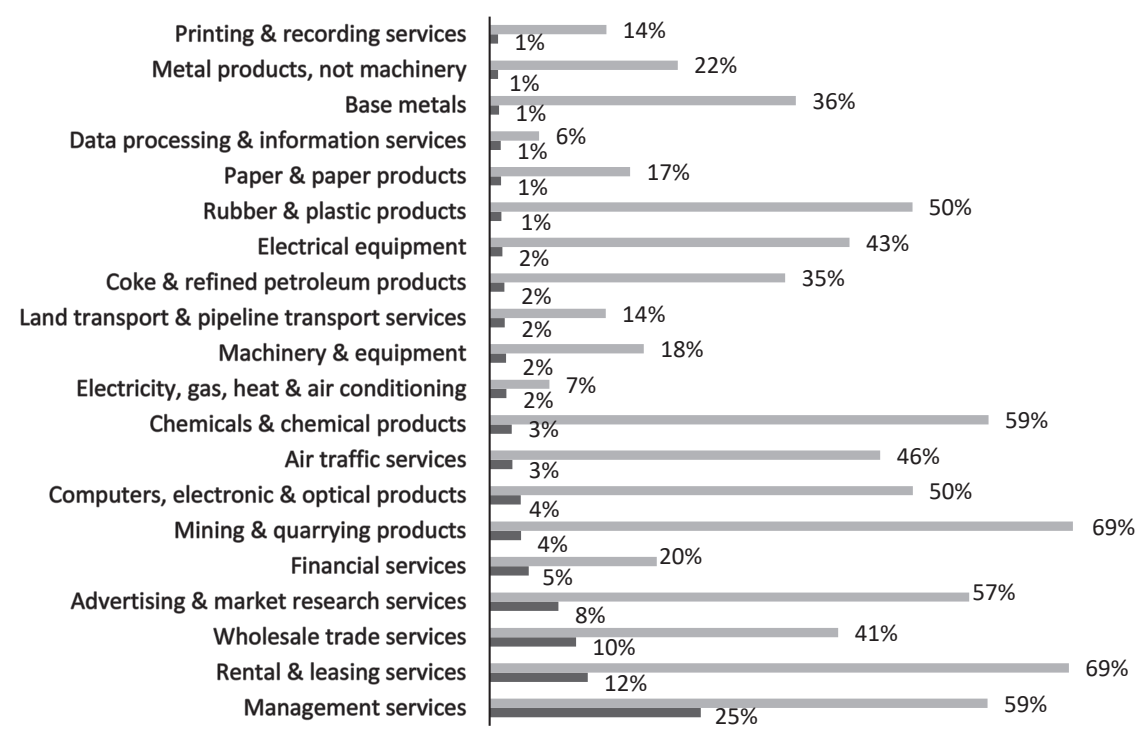

Import dependency of total supply $\quad$ Share of sector's total imports

Fig. 6. Retail services dependency on imports for the total supply of direct and indirect inputs into the sector

\section{Restaurants and food services}

Restaurants and food services in Finland are mainly dependent on domestic supplies, whereby only 19\% (Fig. 1) of the total output is dependent on imported goods and services. Both "management services" and "agricultural $\&$ wild game products" have the largest shares with $9 \%$ of the restaurants and food services sector's total imports of inputs needed for providing the food services (Fig. 7). In contrast with the earlier examined results, "agricultural \& wild game products" have low import dependency of total supply with only $24 \%$ and the majority of supply in "management services" is domestic with import dependency rate of $45 \%$. However, the import dependency of total supply for "mining \& quarrying products" as well as "chemicals \& chemical products" are high with $73 \%$ and $67 \%$ respectively. Therefore, like the earlier examined results, restaurants and food services are dependent on imported fossil fuels concerning energy and chemical inputs required for providing food services in Finland.

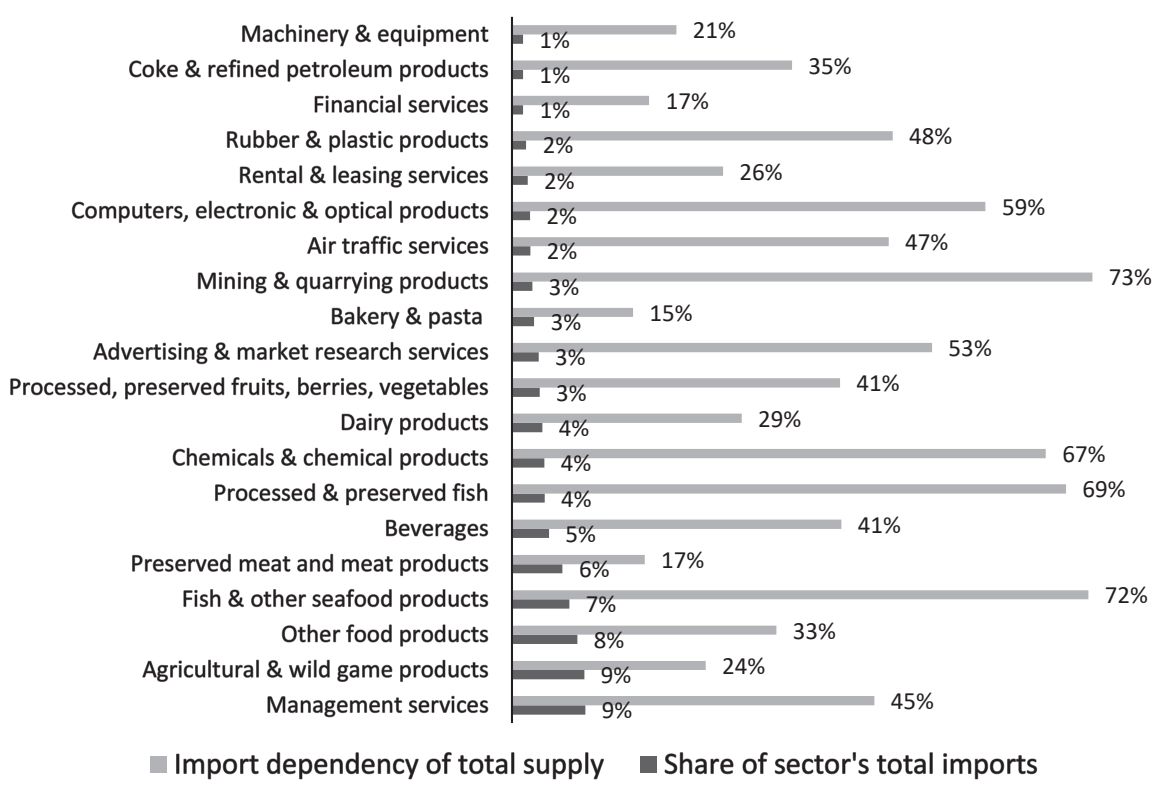

Fig. 7. Restaurants and food services dependency on imports for the total supply of direct and indirect inputs into the sector 


\section{Discussion}

In the current fossil fuel and energy dependent economic system, food production is strongly linked to the security of energy supply and heavily reliant on fossil energy (Pimentel and Pimentel 2003, Woods et al. 2010, Pelletier et al. 2011). Large amount of fossil fuels is required to power heavy farming machinery, to process foods, to refrigerate foods during transportation, to produce packaging materials, and to manufacture and transport chemical inputs such as fertilizers and pesticides. It is well known that the revolution in the yields achieved in the last century can only be explained by the massive injections of fossil energy associated with modern techniques of agricultural production (Conforti and Giampietro 1997, Giampietro et al. 1999, Arizpe et al. 2011). This case study confirms that food production in Finland is reliant on imported fossil energy and another case study concerning Finland's trade dependencies on agricultural inputs conducted by Lehikoinen et al. (2021) using a different approach (physical quantities instead of monetary values), also validates this finding.

Finland is deeply dependent on imported fossil fuels concerning energy and chemical inputs needed not only for primary agricultural production and food processing, but also for distribution services and delivering food services in Finland. Fossil energy from imported inputs of "mining \& quarrying products" is mainly consist of raw materials such as crude oil, coal and natural gas. The study made by Knuuttila and Vatanen (2021) has disclosed that most of the crude oil (87\%), coal (53\%) and natural gas (99\%) are imported from Russia. Furthermore, the study has showed that the majority of fertilisers (63\%) are also imported from Russia, hence Finland is very dependent on Russia not only on the imports of fossil fuels, but also on the imports of fertilisers. According to EU statistics (Eurostat 2020), Russia is the main supplier of crude oil, natural gas and coal to EU countries. Therefore, Finland along with many other EU countries are highly dependent on Russia concerning the imports of fossil fuels for their energy supply. However, EU aims to be climate-neutral by 2050; consequently, there are plans to decarbonise all sectors, including the food sectors, and diminish the use of fossil fuels from EU's energy consumption (EC 2019). Replacing fossil energy with sustainable renewable energy will reduce the reliance on Russia for energy supply in the domestic food sectors as well as mitigate climate change.

The results show that the livestock sector in Finland is highly reliant on the imports of supplementary protein feed. Although Finland's overall protein self-sufficiency rate is high (more than $80 \%$ with grass and cereals), the self-sufficiency rate for supplementary plant-based protein (such as turnip rape, rape, pea, and broad bean products) in animal feed is only $15 \%$. Supplementary protein crops self-sufficiency in Finland is low because cereals dominate the field cropping systems in areas that are also favourable for legumes and rapeseed (PeltonenSainio et al. 2013). It is harder for farmers in Finland to cultivate legumes and rapeseed because these crops are risky and more demanding compared to cereals (Suvanto et al. 2020). In recent years, domestic alternatives such as pea and broad bean have been actively sought and partly replacing imports of supplementary protein feed. However, the substitution of soybeans with domestic feed materials is challenging, especially in poultry feed due to its high amino acid composition. Most of the rapeseed (95\%) is imported within the EU common market from Baltic countries and Germany (Knuuttila and Vatanen 2021). However, almost all soybeans are imported from Brazil and North America. According to the European Parliament (2011), the deficit in the supply of protein feed and crops is also a concern at the EU level because domestic production covers only $30 \%$ of the supplementary protein feed for livestock in the EU. Consequently, 70\% (42 million tonnes in 2009) of the supplementary protein feed consumed by livestock in the EU, especially soymeal, are imported mainly from Brazil, Argentina and the United States. In fact, the growing demand for livestock feed has resulted significant greenhouse gas emissions from land use change due to the expansion of soybean cultivation in Latin America (Castanheira and Freire 2013). Therefore, various promotion measures should be used to promote human consumption of plant-based foods in Finland (Huan-Niemi et al. 2020) and reduce the demand for livestock production in the efforts to lower the overwhelming environmental impacts of land use change in Latin America, especially Brazil, due to the expansion of soybean cultivation for animal feed. Diverting crops to feed humans instead of animals will be beneficial not only for the nature, but also to prevent climate change.

\section{Conclusions}

Security of food supply requires resilient food production and supply chains, effective international trade relations, functioning logistics and infrastructure as well as secured availability of agricultural inputs. This study examined how dependent is agricultural production and the food sectors on imported goods and services with Finland as a case study. The objective is to produce indicators for measuring the import content of the domestic food and service sectors plus the import dependency of the inputs supplied into these sectors. Primary agriculture in Finland 
is heavily dependent on imported fossil fuels concerning chemical and energy inputs required for production as well as high dependence on the imports of supplementary protein feed for livestock production. The dairy products sector, as an example for the food processing sector, is also dependent on imported fossil fuels concerning chemical and energy inputs required for dairy production as well as profound dependence on the imports of supplementary protein feed for livestock in milk production. In the service provider sectors, the retail services are not only reliant on the imports of management services and rental \& leasing services, but also very reliant on imported fossil fuels concerning energy and chemical inputs required for distribution services in Finland. Moreover, the restaurants and food services are also reliant on imported fossil fuels concerning energy and chemical inputs required for providing food services in Finland. Despite of this, the majority of inputs supplied to the Finnish food and service sectors are domestic because only $20 \%$ of the total output is dependent on imported goods and services along with capital goods. The rate of self-sufficiency in food supply is high in Finland, but international trade is essential to provide the necessary energy and chemical inputs needed for food production as well as supplementary protein feed for livestock production.

\section{Acknowledgements}

The authors would like to thank the anonymous reviewers for their comments and suggestions to improve the manuscript. The research was funded by the National Emergency Supply Agency in Finland as well as the Academy of Finland grant (no: 339830) on crisis preparedness and security of supply. The funding from the Academy of Finland was used to write and finalise this article.

\section{References}

Addison, T., Sen, K. \& Tarp, F. 2020. COVID-19: macroeconomic dimensions in the developing world. WIDER Working Paper 2020/74. Helsinki: UNU-WIDER. https://doi.org/10.35188/UNU-WIDER/2020/831-3

Ayas, N. 2017. Import Dependency of Sectors and Major Determinants: An Input Output Analysis. European Journal of Sustainable Development and Research 2: 1-16. https://dergipark.org.tr/tr/download/article-file/279539

Ahtikoski, A., Tuulentie, S., Hallikainen, V., Nivala, V., Vatanen, E., Tyrväinen, L. \& Salminen, H. 2011. Potential trade-offs between nature-based tourism and forestry, a case study in Northern Finland. Forests 2: 894-912. https://doi.org/10.3390/f2040894

Arizpe, N., Giampietro, M. \& Ramos-Martin, J. 2011. Food Security and Fossil Energy Dependence: An International Comparison of the Use of Fossil Energy in Agriculture (1991-2003). Critical Reviews in Plant Sciences 30: 45-63. https://doi.org/10.1080/07 352689.2011 .554352

Baer-Nawrocka, A. \& Sadowski, A. 2019. Food security and food self-sufficiency around the world: A typology of countries. PLoS ONE 14: e0213448. https://doi.org/10.1371/journal.pone.0213448

Bravo, A.C. \& Álvarez, M.T. 2012. The Import Content of the Industrial Sectors in Spain. Economic Bulletin, Banco de España, issue APR. p. 1-12. https://repositorio.bde.es/bitstream/123456789/7915/1/art3e.pdf

Castanheira, E.G. \& Freire, F. 2013. Greenhouse gas assessment of soybean production: implications of land use change and different cultivation systems. Journal of Cleaner Production 54: 49-60. https://doi.org/10.1016/j.jclepro.2013.05.026

Clapp, J. 2017. Food self-sufficiency: Making sense of it, and when it makes sense. Food Policy 66: 88-96. https://doi.org/10.1016/j.foodpol.2016.12.001

Conforti, P. \& Giampietro, M. 1997. Fossil energy use in agriculture: an international comparison. Agriculture, Ecosystems \& Environment 65: 231-243. https://doi.org/10.1016/S0167-8809(97)00048-0

Cuihong, Y. \& Jiansuo, P. 2007. Import Dependency of Foreign Trade: A case of China. The 16th International Conference on InputOutput Techniques, July 2-6, 2007, Istanbul, Turkey. https://www.iioa.org/conferences/16th/papers.html

D'Odorico, P., Carr, J.A., Laio, F., Ridolfi, L. \& Vandoni, S. 2014. Feeding humanity through global food trade. Earth's Future 2: 458469. https://doi.org/10.1002/2014EF000250

EC 2019. The European Green Deal. Communication from the Commission to the European Parliament, the European Council, the European Economic and Social Committee and Committee of the Regions. COM (2019) 640 final. https://eur-lex.europa.eu/legal-content/EN/TXT/?uri=CELEX\%3A52019DC0640\&qid=1628834356826

European Parliament 2011. The EU protein deficit: what solution for a long-standing problem? Rapporteur: Martin Häusling, Report 4.2.2011. Committee on Agriculture and Rural Development. Brussels, Belgium.

https://www.europarl.europa.eu/doceo/document/A-7-2011-0026_EN.htm

Eurostat 2020. Energy production and imports. Statistical office of the European Union. https://ec.europa.eu/eurostat/statisticsexplained/index.php/Energy_production_and_imports

FAO 2006. Food Security. Policy Brief, June 2006, Issue 2. Food and Agriculture Organization of the United Nations (FAO). http://www.fao.org/fileadmin/templates/faoitaly/documents/pdf/pdf_Food_Security_Cocept_Note.pdf

FAO 2020. Policy responses to keep input markets flowing in times of COVID-19. Food and Agriculture Organization of the United Nations (FAO). http://www.fao.org/3/ca8979en/CA8979EN.pdf

Finnish Customs 2020. Uljas statistical database. https://uljas.tulli.fi. (in Finnish). 
Foley, J.A., DeFries, R., Asner, G.P., Barford, C.,Bonan, G., Carpenter, S.R., Chapin, S., Coe, M.T., Daily, G.C., Gibbs, H.K., Helkowski, J.H., Holloway, T., Howard, E.A., Kucharik, C.J., Monfreda, C., Patzl, J.A., Prentice, C., Ramankutty, N. \& Snyder, P.K. 2005. Global Consequences of Land Use. Science 309: 570-574. https://doi.org/10.1126/science.1111772

Ghose, B. 2014. Food security and food self-sufficiency in China: from past to 2050. Food and Energy Security 3: 86-95. https://doi.org/10.1002/fes3.48

Giampietro, M., Bukkens, S.G.F. \& Pimentel, D. 1999. General Trends of Technological Changes in Agriculture. Critical Reviews in Plant Sciences 18: 261-282. https://doi.org/10.1080/07352689991309225

Godfray, H.C.J., Beddington, J.R., Crute, I.R., Haddad, L., Lawrence, D., Muir, J.F., Pretty, J., Robinson, S., Thomas, S.M. \& Toulmin, C. 2010. Food Security: The Challenge of Feeding 9 Billion People. Science 327: 812-818. https://doi.org/10.1126/science.1185383

Hamilton-Hart, N. 2019. Indonesia's Quest for Food Self-sufficiency: A New Agricultural Political Economy? Journal of Contemporary Asia 49: 734-758. https://doi.org/10.1080/00472336.2019.1617890. https://doi.org/10.1080/00472336.2019.1617890

Huan-Niemi, E., Kaljonen, M., Knuuttila, M., Niemi, J. \& Saarinen, M. 2020. The impacts of dietary change in Finland: food system approach. Agricultural and Food Science 29: 372-382. https://doi.org/10.23986/afsci.95282

Knuuttila, M. \& Vatanen, E. 2021. Food market import dependence in 2003-2016. Natural resources and bioeconomy study 44/2021. Natural Resources Institute Finland (Luke). http://urn.fi/URN:ISBN:978-952-380-231-5. (in Finnish, abstract in English).

Knuuttila, M., Vatanen, E. \& Jansik, C. 2007. Finnish food industry in 1989-2002: an output-oriented input-output analysis. Acta Agriculturae Scandinavica, Section C: Food Economics 4: 217-228. https://doi.org/10.1080/16507540701747635

Lehikoinen, E., Kinnunen, P., Piipponen, J., Heslin, A., Puma, M.J. \& Kummu, M. 2021. Importance of trade dependencies for agricultural inputs: a case study of Finland. Environmental Research Communications 3: 061003.

https://doi.org/10.1088/2515-7620/ac02d0

Leontief, W. 1936. Quantitative input-output relations in the economic system. Review of Economic Statistics 18: 105-125. https://doi.org/10.2307/1927837

Loschky, A. \& Ritter, L. 2007. Import Content of Exports. The 16th International Conference on Input Output Techniques, July 2-6, 2007, Istanbul, Turkey. https://www.iioa.org/conferences/16th/papers.html.

Marshall, K. 2011. The Factor Content of Chinese Trade. The Journal of International Trade \& Economic Development: An International and Comparative Review 20: 769-787. https://doi.org/10.1080/09638190903318194

Miller, R. \& Blair, P. 2009. Input-Output Analysis: Foundations and Extensions. New York, USA: Cambridge University Press. https://doi.org/10.1017/CBO9780511626982

Niemi, J.K. \& Niskanen, M. 2019. Use and sources of vegetable protein in 2018. Plant and animal protein balances from 2010 to 2018. Natural Resources Institute Finland (Luke). http://urn.fi/URN:NBN:fi-fe202001011012 (in Finnish).

Pelletier, N., Audsley, E., Brodt, S., Garnett, T., Henrikkson, P., Kendall, A., Kramer, K., Murphy, D., Nemecek, T. \& Troell, M. 2011. Energy intensity of agriculture and food systems. Annual Review of Environment and Resources 36: 223-246.

https://doi.org/10.1146/annurev-environ-081710-161014

Peltonen-Sainio, P., Hannukkala, A., Huusela-Veistola, E., Voutila, L., Niemi, J., Valaja, J., Jauhiainen, L. \& Hakala, K. 2013. Potential and realities of enhancing rapeseed- and grain legume-based protein production in a northern climate. The Journal of Agricultural Science 151: 303-321. https://doi.org/10.1017/S002185961200038X

Pimentel, D. \& Pimentel, M. 2003. Sustainability of meat-based and plant-based diets and the environment. The American Journal of Clinical Nutrition 78: 660S-663S. https://doi.org/10.1093/ajen/78.3.660S

Porkka, M., Kummu, M., Siebert, S. \& Varis, O. 2013. From Food Insufficiency towards Trade Dependency: A Historical Analysis of Global Food Availability. PLoS ONE 8: e82714. https://doi.org/10.1371/journal.pone.0082714

Statistics Finland 2020a. Detailed input-output data 2008-2016. Separate data was ordered for the year 2016 and obtained from Statistics Finland on August 13th, 2020.

Statistics Finland 2020b. National Accounts. https://www.stat.fi/til/vtp/tau_en.html

Statistics Finland 2020c. Standard Industrial Classification TOL 2008. https://www.stat.fi/en/luokitukset/toimiala/toimiala_1_20080101/

Sen, K. 2020. COVID-19 and socioeconomic impact in Asia: The case of India. WIDER Background Note 2020/1. Helsinki: UNU-WIDER. https://doi.org/10.35188/UNU-WIDER/WBN/2020-1

Suvanto, H., Niemi, J.K. \& Lähdesmäki, M. 2020. Entrepreneurial identity and farmers' protein crop cultivation choices. Journal of Rural Studies 75:174-184.https://doi.org/10.1016/j.jrurstud.2020.01.022

Szyrmer, J.M. 1992. Input-Output Coefficients and Multipliers from a Total-Flow Perspective. Environment and Planning A: Economy and Space 24:921-937. https://doi.org/10.1068/a240921

Tilman, D., Fargione, J., Wolff, B., D’Antonio, C., Dobson, A., Howarth, R., Schindler, D., Schlesinger, W.H., Simberloff, D. \& Swackhamer, D. 2001. Forecasting Agriculturally Driven Global Environmental Change. Science 292: 281-284. https://doi.org/10.1126/science.1057544

Vatanen, E. 2001. Local economic effects of timber harvesting and timber transport in Juva, Keuruu and Pielinen Karelia regions. Communications from the Finnish Forest Research Institute 825, 2001. Joensuu Research Center. (in Finnish).

Vatanen, E. 2011. The Output Model in Input-Output Analysis - the Method, Theoretical Underpinnings and Empirical Applications at a Local and Regional level. Publications of the University of Eastern Finland. Dissertations in Social Sciences and Business Studies. N:o 19. (in Finnish).

Wegren, S.K. \& Elvestad, C. 2018. Russia's food self-sufficiency and food security: an assessment. Post-Communist Economies 30: 565-587. https://doi.org/10.1080/14631377.2018.1470854

Woods, J., Williams, A., Hughes, J.K., Black, M. \& Murphy, R. 2010. Energy and the food system. Philosophical Transactions of The Royal Society B 365: 2991-3006. https://doi.org/10.1098/rstb.2010.0172 